\title{
GIS W NOWYCH PODSTAWACH PROGRAMOWYCH GEOGRAFII
}

\begin{abstract}
Zarys treści: W ostatnich latach są podejmowane działania edukacyjne, których efektem jest m.in. zmiana filozofii i sposobów kształcenia geograficznego, związana z rozwojem gospodarki opartej na wiedzy oraz technologii cyfrowych. W artykule omówiono ogólne założenia i kierunki zmian w nowych podstawach programowych geografii dla szkoły podstawowej i ponadpodstawowej, ze szczególnym podkreśleniem potrzeby i znaczenia uwzględnienia wymagań z zakresu technologii geoinformacyjnych i Systemów Informacji Geograficznej (GIS; ang. Geographic Information Systems). Jednocześnie wyjaśniono znaczenie powyższych terminów, ponieważ właściwe rozumienie jest kluczowe dla poprawnego posługiwania się nimi. Zaprezentowano także odpowiednie zapisy zawarte w podstawach programowych. Ponieważ wprowadzenie GIS do edukacji szkolnej w takim wymiarze stanowi nową sytuację i duże wyzwanie dla nauczycieli, zwrócono także uwagę na możliwe trudności i ograniczenia w realizacji założeń podstawy programowej, podkreślając jednocześnie jak ważne jest także podjęcie konkretnych rozwiązań i propozycji w zakresie dokształcania nauczycieli w związku z zaprezentowanymi zmianami programowymi.
\end{abstract}

Słowa kluczowe: technologie geoinformacyjne, Systemy Informacji Geograficznej (GIS), nowa podstawa programowa dla szkół ponadpodstawowych, geografia.

\section{Wprowadzenie}

Wśród narastającej lawinowo ilości informacji o otaczającym nas świecie, znaczną część stanowią te, które odnoszą się do przestrzeni, a w niej obiektów, zjawisk i procesów wraz z ich lokalizacją, zasięgiem, zmiennością, ciągłością, natężeniem i właściwościami. Ich poznawanie, przedstawianie oraz interpretowanie jest możliwe przy zastosowaniu technologii geoinformacyjnych i Systemów Informacji Geograficznej (GIS).

Zarówno w niniejszym artykule, a przede wszystkim w podstawach programowych geografii na poziomie szkoły podstawowej i ponadpodstawowej, stosuje się pojęcia: technologie geoinformacyjne i Systemy Informacji Geograficznej (GIS). Aby być dobrze zrozumianym, wymagają one wyjaśnienia. Warto więc 
zwrócić uwagę na fakt, że już od lat 70 . XX wieku pojawiały się co jakiś czas próby zdefiniowania GIS, które miały ułatwić jego rozumienie, a były rozwijane i wzbogacane poprzez włączanie efektów wypracowanych przez naukę. Wielu autorów podkreśla rolę GIS w kształceniu i rozwoju oraz coraz większym zastosowaniu w różnych dziedzinach i działalności (Gaździcki 2006, 2009; Zwoliński 2009ab, 2010; Jażdżewska 2015; Jażdżewska i in. 2015). Jednak z uwagi na dynamiczny rozwój GIS, jego zastosowań, interdyscyplinarny charakter, a przede wszystkim różne jego rozumienie i pojawiające się odmienne określenia, Z. Zwoliński (2010) oraz J. Gaździcki i in. (2018) zauważyli pewne zaistniałe zamieszanie terminologiczne, które wymaga uporządkowania. Dlatego też w artykule pt. Aktualne aspekty edukacji geoprzestrzennej w Polsce (Gaździcki i in. 2018) zwrócili uwagę na funkcjonowanie zróżnicowanego nazewnictwa, które pojawia się w zależności od obszaru lub kraju. Wymienili istniejące określenia, takie jak: informacja przestrzenna, informacja geoprzestrzenna, termin geoinformacja zaproponowany jako następstwo zamiany systemów informacji geograficznej (GISystems) na naukę o informacji geograficznej (GIScience) czy technologia informacji geoprzestrzennej. Jednocześnie podkreślili, że nadal utrzymano termin Systemy Informacji Geograficznej z uwagi na jego stosowanie w cyklicznych już wydarzeniach, takich jak GIS Day, GIS w nauce czy GIS w edukacji.

W tym samym opracowaniu (Gaździcki i in. 2018) autorzy wykazali się bardzo cenną inicjatywą, proponując termin edukacja geoprzestrzenna (geospatial education) rozumianą jako edukacja $\mathrm{w}$ zakresie nauki i technologii informacji geoprzestrzennej. Zwrócili szczególną uwagę na jej cechy, jak „wielopoziomowość, wielodyscyplinarność i wielotematyczność rozwoju edukacji geoprzestrzennej”.

Jak pisał Z. Zwoliński (2009a), technologie geoinformacyjne są ściśle związane z pozyskiwaniem informacji/danych, ich przechowywaniem, przetwarzaniem, analizą, udostępnianiem oraz wizualizacją. W związku z tym jest możliwość obrazowania związków, które zachodzą między obiektami i zjawiskami w przestrzeni geograficznej. Dzięki temu możliwa jest interpretacja takich zagadnień, jak lokalizacja, warunki, tendencje, prawidłowości oraz przeprowadzanie modelowania. Aby społeczeństwo mogło funkcjonować w świecie, w którym podstawą jest pozyskiwanie informacji geoprzestrzennej oraz jej przetwarzanie, konieczna jest właściwa w takim zakresie edukacja zapewniająca nie tylko określony zakres merytoryczny, ale przede wszystkim wykształcenie odpowiednich umiejętności (Piotrowska 2018).

Pierwsze próby wprowadzania technologii geoinformacyjnych oraz Systemów Informacji Geograficznej (GIS) do edukacji szkolnej zostały podjęte w ramach wydarzenia o charakterze międzynarodowym GIS Day (od 1999 roku organizowany na świecie, a w Polsce od 2001 roku), w czasie którego uczniowie szkół wszystkich poziomów edukacyjnych mają możliwość zapoznania się z wiedzą geoinformacyjną. Do kolejnych inicjatyw należą: projekt Akademia EduGIS realizowany przez Centrum UNEP/GRID - Warszawa w latach 2010-2011 - w wyniku 
realizacji tego projektu powstała publikacja GIS w szkole... (2011), działania szkoleniowe Esri Polska oraz warsztaty podczas ostatnich Olimpiad Geograficznych. Na uwagę zasługują także opracowania naukowe dotyczące GIS oraz propozycje wykorzystania w edukacji geograficznej (Piotrowska 1996; Nita, Waga 2004; Kroczak 2012; Głowacz 2015; Samulowska, Wyka 2015).

W opracowanych w latach 2016-2018 nowych podstawach programowych geografii - dokumentach prawnych precyzyjnie określających wymagania wobec uczniów i nauczycieli (MEN 2017; MEN 2018a; MEN 2018b) podjęta została próba znacznie szerszego niż dotychczas wprowadzenia technologii geoinformacyjnych do kształcenia geograficznego. Szczególnie dużo zapisów wymagań odnoszących się do GIS znalazło się w szkole ponadpodstawowej - liceum i technikum (MEN 2018a).

Celem artykułu jest zaprezentowanie nowych założeń i koncepcji kształcenia geograficznego oraz wynikających z nich możliwości wykorzystania technologii geoinformacyjnych w szkole. Natomiast efektem jest zwrócenie uwagi na konkretne zapisy ogólnych celów kształcenia i wymagań szczegółowych nawiązujących do stosowania GIS oraz identyfikacja ograniczeń i trudności w realizacji założeń podstawy programowej.

\section{Ogólne zalożenia i kierunki zmian w podstawie programowej z geografii}

Koncepcja kształcenia geograficznego zawarta w podstawie programowej opracowanej i wprowadzonej do szkół w ostatnich trzech latach, oparta została na przekonaniu, że współczesna edukacja geograficzna powinna odwoływać się zarówno do najlepszych polskich tradycji edukacyjnych, kontynuacji idei kształcenia geograficznego wypracowanych przez polskich geografów i dydaktyków geografii w ostatnim stuleciu, jak również uwzględniać aktualne potrzeby i wyzwania stwarzane przez szybko postępujące zmiany kulturowo-cywilizacyjne, ekonomiczne i geopolityczne zachodzące w polskim społeczeństwie oraz na świecie (Szkurłat i in. 2016). Najważniejsze elementy tej koncepcji przedstawia poniższy schemat (ryc. 1).

$\mathrm{W}$ tworzeniu podstaw programowych geografii do szkół podstawowych, ponadpodstawowych i branżowych przyjęto założenie, że główną osią programową geografii jest integrowanie wiedzy ucznia o środowisku przyrodniczym z wiedzą społeczno-ekonomiczną i humanistyczną. Jest to walor geografii, który był dostrzegany i eksponowany w pracach wielkich geografów w ostatnim stuleciu, natomiast $\mathrm{w}$ ostatnich dziesięcioleciach był mało eksponowany i wykorzystywany zarówno w argumentowaniu rangi geografii na poziomie edukacji szkolnej, jak i, co niezwykle istotne, na poziomie akademickim. Ogromną stratą dla geografii jako dziedziny wiedzy jest pomijanie wskutek tego jej roli w tworzeniu całościowego obrazu świata oraz integrowaniu wiedzy rozbitej w wyniku podziału najpierw na geografię fizyczną i społeczno-ekonomiczną, a następnie rozczłonkowaną w efekcie podziału na wiele subdyscyplin (Hibszer i in. 2017; 


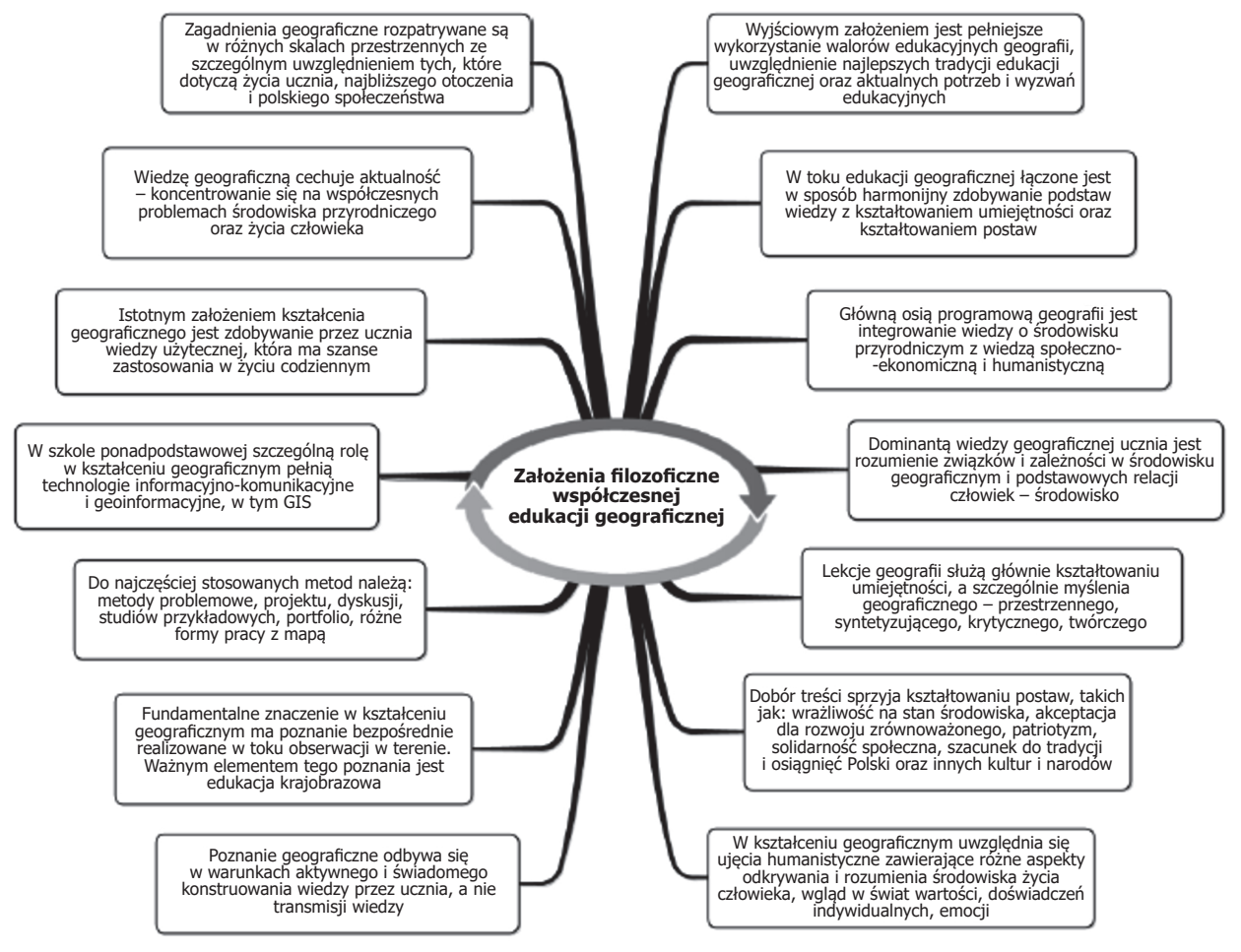

Ryc. 1. Założenia filozoficzne nowej podstawy programowej geografii Źródło: opracowanie E. Szkurłat.

Piotrowska i in. 2017; Szkurłat i in. 2017b). Konsekwencją przyjętego założenia jest taka konstrukcja zapisów podstawy programowej, aby dominującym celem działań poznawczych uczniów było identyfikowanie, a przede wszystkim rozumienie związków i zależności występujących w środowisku przyrodniczym oraz relacji przyroda-człowiek (MEN 2017; MEN 2018a; MEN 2018b). Rozumienie współzależności zjawisk powoduje, że geografia staje się - jak pragnął Wacław Nałkowski - ,geografią rozumową”, sprzyjającą kształtowaniu „zmysłu geograficznego", pozwalającą widzieć, że środowisko geograficzne lub krajobraz to system powiązanych ze sobą elementów i jakakolwiek ingerencja w jeden z elementów oznacza konsekwencje dla wielu innych (Szkurłat 2011). Dzięki ujęciom relacyjnym podlega również kształtowaniu umiejętność argumentacji, wielostronnej oceny zagadnienia - w miejsce bezkrytycznego przyjmowania skrajnych, jednostronnych interpretacji zjawisk i procesów. Geografia w nowej koncepcji edukacji szkolnej powinna sprzyjać poszukiwaniu odpowiedzi na ważne pytania odnoszące się do problemów współczesnej egzystencji człowieka, jego funkcjonowania w środowisku przyrodniczym, społeczno- 
-gospodarczym i politycznym tak, aby zapewnić orientację młodych ludzi w narastających powiązaniach we współczesnym świecie.

Nowa podstawa programowa w szczególny sposób sprzyjać powinna kształtowaniu umiejętności. Jak powiedziano wyżej, kluczową dla rozumienia relacji przyroda-człowiek umiejętnością jest określanie związków i zależności. Inne, bardzo ważne umiejętności, których kształtowanie umożliwiają zapisy nowej podstawy programowej przedstawiono w sposób syntetyczny na schemacie (ryc. 2).

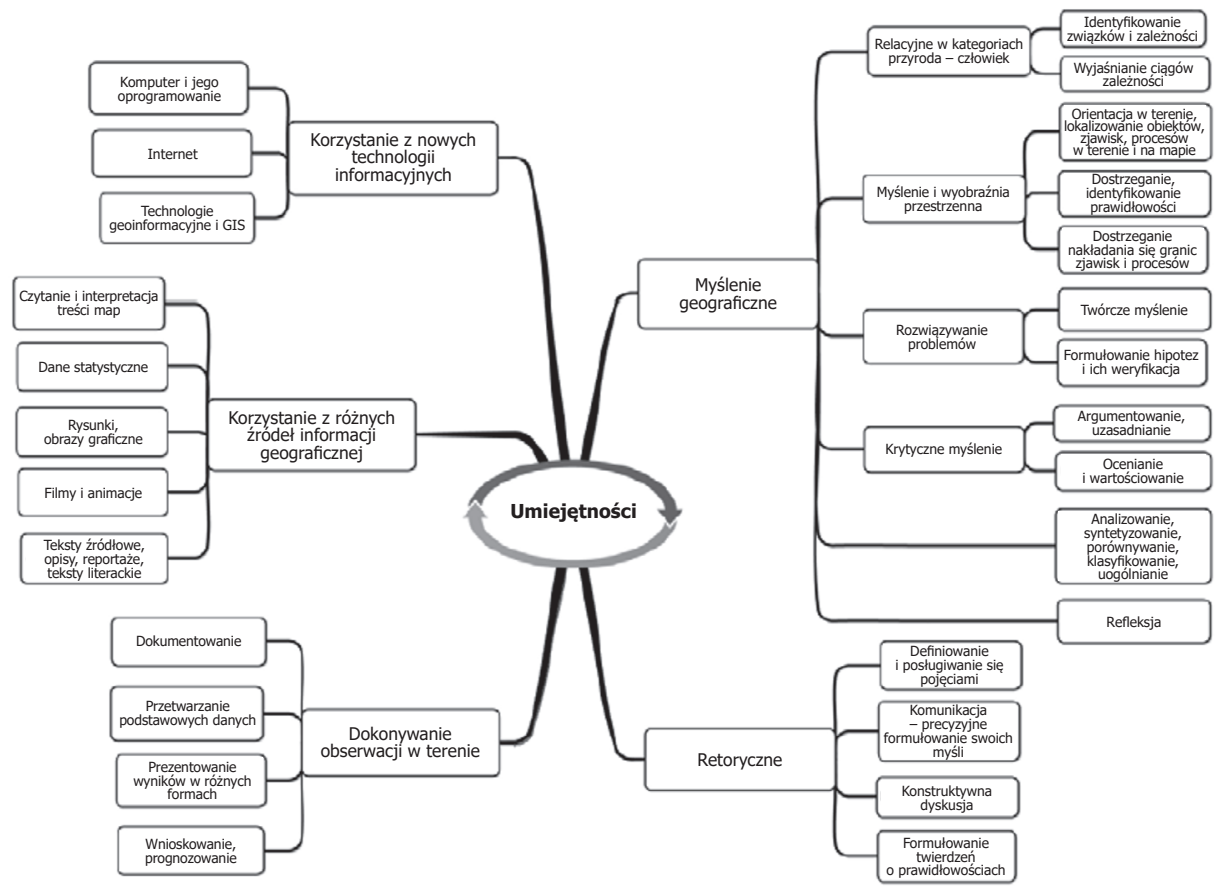

Ryc. 2. Umiejętności, których kształtowanie zakładają nowe podstawy programowe geografii

Źródło: opracowanie E. Szkurłat.

Kolejnym ważnym założeniem podstawy programowej jest wykorzystanie walorów wychowawczych geografii. Dobór treści w podstawie programowej sprzyja m.in. kształtowaniu takich postaw, jak: rozumienie potrzeby racjonalnego gospodarowania $\mathrm{w}$ środowisku geograficznym zgodnie $\mathrm{z}$ zasadami zrównoważonego rozwoju, uwrażliwianie na wartość i znaczenie zachowania dla przyszłych pokoleń cennych obiektów przyrodniczych i kulturowych, należących do dziedzictwa lokalnego, regionalnego, narodowego, ponadnarodowego. Treści geograficzne powinny też sprzyjać kształtowaniu postawy solidarności społecznej, szacunku i empatii wobec przedstawicieli innych narodów i grup etnicznych, przyjmowania 
postawy patriotycznej, wspólnotowej i obywatelskiej. Ważnym celem edukacyjnym jest rozumienie przez uczniów pozautylitarnych wartości środowiska przyrodniczego i kulturowego oraz rozwijanie dociekliwości poznawczej, ukierunkowanej na poszukiwanie prawdy, dobra i piękna.

Do edukacji geograficznej zalecane jest wprowadzanie elementów ujęć humanistycznych - pozwalających na wgląd w świat wartości, indywidualnych doświadczeń i emocji, który może być pomocny m.in. w pełniejszym odkrywaniu i rozumieniu środowiska życia człowieka. Ujęcia humanistyczne sprzyjać powinny rozwijaniu myślenia refleksyjnego i kontemplacji (dostrzegania m.in. piękna i harmonii, brzydoty i chaosu, konieczności empatii i wrażliwości na potrzeby człowieka).

Zgodnie z założeniami podstaw programowych, poznanie geograficzne powinno odbywać się w warunkach aktywnego i świadomego konstruowania wiedzy przez ucznia, a nie transmisji wiedzy, czemu mają służyć wykorzystywane $\mathrm{w}$ procesie kształcenia metody problemowe, projektu, seminarium, debaty $\mathrm{i}$ in. (MEN 2018: 189-190). Podstawowymi metodami badawczymi umożliwiającymi uczniowi poznawanie środowiska geograficznego są obserwacje bezpośrednie i pomiary. Wykorzystanie wymienionych metod wynika z faktu, że szczególną rolę w edukacji geograficznej pełnią zajęcia w terenie. Ich obecność umożliwia kształtowanie umiejętności wykorzystania podstawowych metod badawczych, takich jak wywiady, badania ankietowe czy analiza kartograficzna, które służą konstruowaniu wiedzy ucznia w procesie bezpośredniego poznawania rzeczywistości.

Na szczególną uwagę w nowych podstawach programowych zasługuje mocny akcent położony na wykorzystanie technologii informacyjno-komunikacyjnych i geoinformacyjnych (GIS) w poznawaniu świata, pozyskiwaniu oraz tworzeniu zbiorów danych przestrzennych, ich analizy i prezentacji. Stosowanie technologii geoinformacyjnych zdecydowanie rozszerza możliwości sfery poznawczej ucznia, a w powiązaniu z wybranymi elementami geografii fizycznej i społeczno-ekonomicznej czyni z geografii nowoczesną dziedzinę wiedzy.

Podstawa programowa stwarza warunki do wprowadzania w kształceniu geograficznym podstaw wiedzy praktycznej, przydatnej w życiu codziennym (Szkurłat i in. 2017a). Jej zapisy, mają przyczyniać się m.in. do pogłębionego rozumienia sensu i warunków realizacji zasad zrównoważonego rozwoju, m.in. poprzez poznawanie przykładów racjonalnego gospodarowania w środowisku geograficznym, jego oceny w zamieszkiwanej miejscowości, poczucia odpowiedzialności za tworzenie ładu przestrzennego w miejscach swego życia.

Powyżej przedstawione założenia filozoficzne oraz idee edukacyjne wypracowane przez zespół ekspertów MEN, stały się wyznacznikiem trwających trzy lata (2016-2018) prac nad zmianami zapisów w podstawie programowej geografii dla szkół podstawowych, ponadpodstawowych (liceum i technikum) oraz szkół branżowych. Konsekwentne stosowanie przyjętych założeń w połączeniu ze 
zwiększeniem liczby godzin geografii (głównie w szkołach ponadpodstawowych), wydaje się tworzyć korzystne, wyjściowe warunki zmian w kierunku podniesienia jakości kształcenia geograficznego.

\section{Dlaczego technologie geoinformacyjne i GIS w szkole?}

Potrzeba wprowadzenia technologii geoinformacyjnych i GIS do szkolnej edukacji geograficznej wynika z rozwoju nauki i cywilizacji oraz przyjętych koncepcji kształcenia. Przedstawione poniżej na schemacie walory i argumenty przemawiają za szerszym wprowadzeniem technologii geoinformacyjnych do edukacji szkolnej (ryc. 3).

Na szczególną uwagę zasługują możliwości pozwalające na: kształcenie myślenia przestrzennego, myślenia komputacyjnego w rozwiązywaniu problemów, precyzyjniejszą identyfikację granic, ułatwienia w identyfikowaniu prawidłowości geograficznych czy śledzenia aktualnego stanu i zmian w środowisku przyrodniczym.

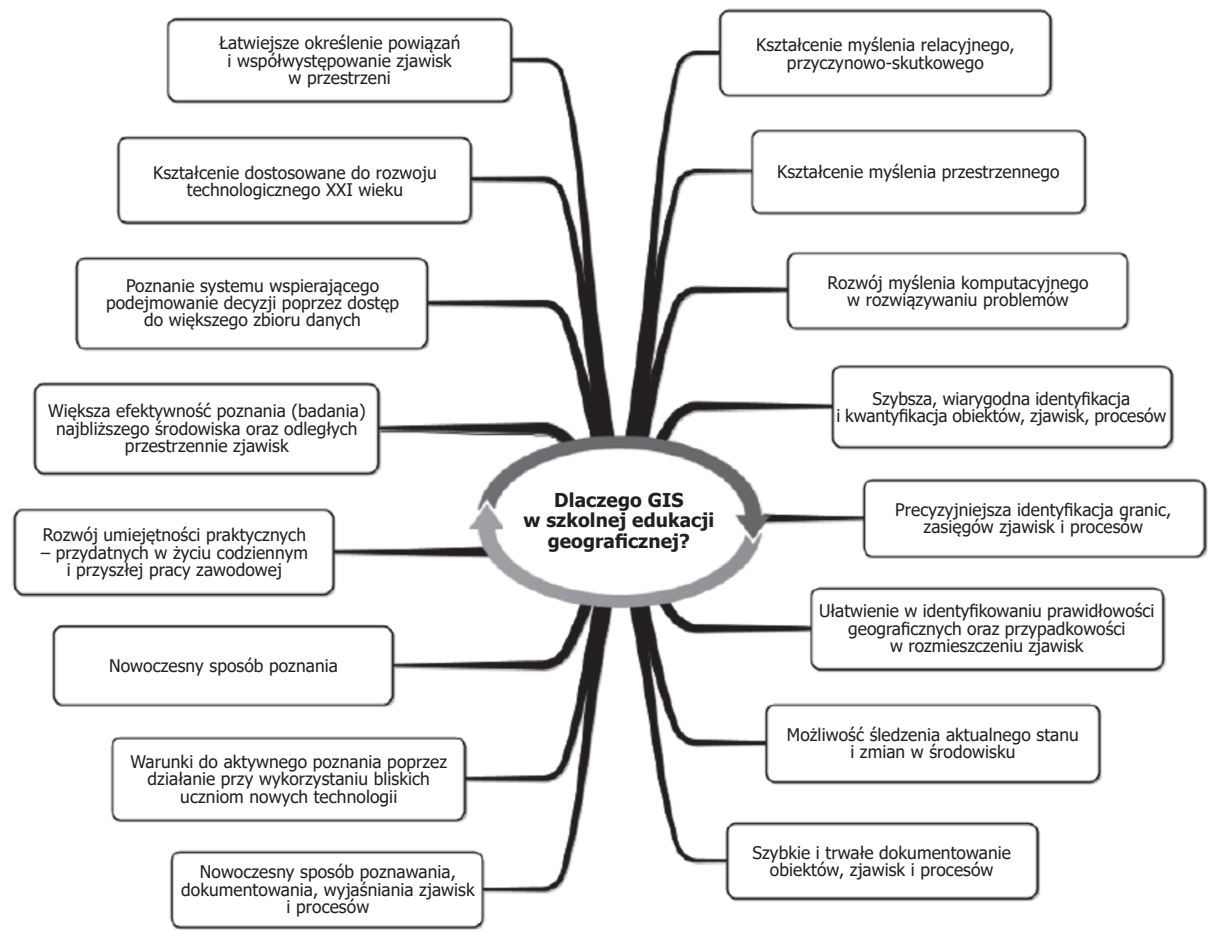

Ryc. 3. Walory wykorzystania technologii geoinformacyjnych

w szkolnej edukacji geograficznej

Źródło: opracowanie E. Szkurłat. 
Zatem wśród wymienionych walorów występują i takie, które odnoszą się zarówno do budowy pewnych postaw czy też podejścia do kształcenia w ujęciu ogólnym, jak również i takie, które dotyczą już bardzo konkretnych umiejętności związanych z wykorzystaniem technologii geoinformacyjnych.

\section{Technologie geoinformacyjne i GIS w nowych podstawach programowych geografii}

Zgodnie z przedstawionymi powyżej założeniami filozoficznymi podstawy programowej (ryc. 1 i 2) oraz przy uwzględnieniu potencjalnych walorów wykorzystania technologii geoinformacyjnych (ryc. 3), wprowadzone zostały stosowne zapisy celów i treści w języku efektów kształcenia. Ta przyjęta forma zapisu - zalecona przez Parlament Europejski w dniu 23 kwietnia 2008 roku w sprawie ustanowienia Europejskich Ram Kwalifikacji dla uczenia się przez całe życie (Zalecenie Parlamentu Europejskiego i Rady, 2008)', spowodowała wprowadzenie także i do polskich dokumentów oświatowych określonych sposobów zapisów wymagań programowych. Cel edukacyjny definiuje się jako świadomie określony, przewidywany i sformułowany wynik działalności dydaktycznej, tzw. efekt pracy ucznia. Natomiast za efekt uczenia się przyjmuje się, że jest to: „to co uczący wie, rozumie i potrafi wykonać po ukończeniu procesu uczenia się" (Europejskie Ramy... 2008: 3). Wobec tego, tak sformułowane zapisy precyzyjnie określają zakres merytoryczny, który opanować musi każdy uczeń. Wydaje się, że jest to odpowiednia forma, umożliwiająca zachowanie porównywalności merytorycznej procesu kształcenia geograficznego prowadzonego w różnych warunkach. Sformułowane cele ogólne zachowują duży stopień ogólności, natomiast wymagania są bardzo konkretne, jednoznaczne, precyzyjne i według autorów powinny one ułatwić nauczycielom realizację zajęć dydaktycznych. Należy stwierdzić, że w ciągu kilkunastu lat obecności podstaw programowych w polskiej szkole, nastąpiło zwiększenie liczby efektów dotyczących GIS i technologii geoinformacyjnych (Piotrowska 2018).

W podstawie programowej geografii do szkoły podstawowej (MEN 2017), występuje niewiele zapisów dotyczących GIS, ponieważ akcent położono na poziomie ponadpodstawowym. Zatem widoczne są tylko bardzo ogólne zapisy przytoczone zgodnie z dokumentem podstawy programowej (MEN 2017): „Realizacja celów kształcenia geograficznego powinna odbywać się przez: (2) traktowanie mapy (w tym cyfrowej) jako podstawowego źródła informacji oraz pomocy służącej kształtowaniu umiejętności myślenia geograficznego; (3) wykorzystanie technologii informacyjno-komunikacyjnych do pozyskiwania, gromadzenia, analizy i prezentacji informacji o środowisku geograficznym i działalności człowieka”.

\footnotetext{
${ }^{1}$ Dz.Urz.UE C 111 z dnia 6 maja 2008 r.
} 
Takie ujęcie ma jedynie zwrócić uwagę na nowe, z punktu widzenia dokumentów programowych MEN, niemniej już istniejące wykorzystanie technologii cyfrowych. Nowością w zapisie celów jest termin „mapa cyfrowa”, który nie pojawiał się we wcześniej obowiązujących podstawach programowych.

Zasadnicze i największe zmiany w zakresie nowych technologii i GIS zostały wprowadzone $\mathrm{w}$ podstawie programowej dla szkół ponadpodstawowych (MEN 2018). Pojawiła się właściwa terminologia, jednak nowością są konkretne wymagania $\mathrm{w}$ odniesieniu do GIS, powiązane z określonym zakresem merytorycznym zarówno geografii fizycznej, jak i społeczno-ekonomicznej. W tabeli 1 umieszczone zostały wybrane z całej podstawy programowej treści oraz wymagania dotyczące GIS i technologii geoinformacyjnych. Zamieszczono obydwa zakresy przewidziane dla szkoły ponadpodstawowej - zakres podstawowy i rozszerzony po to, aby widoczny był zdecydowany przyrost treści i umiejętności stosowania GIS czy też aplikacji internetowych.

Można postawić pytanie: jakie jest znaczenie dla kształcenia geograficznego włączenie tematyki dotyczącej GIS do podstawy programowej w szkole? Patrząc perspektywicznie jest ono bardzo duże (Piotrowska 2018). W zakresie podstawowym i rozszerzonym podstawy programowej, ważną rolę przypisuje się nadal źródłom informacji geograficznej, których wykorzystanie umożliwia uczniom kształtowanie umiejętności wyszukiwania wiadomości o różnych zjawiskach, procesach i obiektach geograficznych w różnych skalach przestrzennych, od lokalnej po globalną. Te umiejętności w połączeniu ze stosowaniem technologii geoinformacyjnych umożliwiają przetwarzanie pozyskanych danych statystycznych i przestrzennych.

Wielką uwagę w edukacji geograficznej przywiązuje się do zajęć terenowych. W zapisach podstawy na poziomie rozszerzonym akcentuje się to, że geografia przygotowuje ucznia do stosowania różnych metod badawczych, poprzez bezpośrednie pomiary w terenie, badania ankietowe, po analizę kartograficzną. To z kolei w połączeniu z technologią geoinformacyjną oznacza pozyskiwanie, tworzenie zbiorów danych przestrzennych, przechowywanie, przetwarzanie, analizę i prezentację. Wydaje się więc, że znajomość i wykorzystanie technologii geoinformacyjnych i GIS przyczynia się do traktowania geografii jako bardziej nowoczesnej dyscypliny, jednocześnie umożliwiając kształcenie wielu ważnych umiejętności. Wśród umiejętności szczególnie rozwijanych przez stosowanie technologii geoinformacyjnych należy wymienić:

- wyszukiwanie wybranych lokalizacji na mapie,

- wyszukiwanie danych i informacji w geoportalach,

- pobieranie informacji i dokumentów z różnych źródel,

- obsługa narzędzia mapy (nawigacja po mapie),

- analiza zdjęć lotniczych i satelitarnych,

- ocena aktualności i wiarygodności danych, 
Tabela 1. Technologie geoinformacyjne i GIS w nowej podstawie programowej geografii w szkole ponadpodstawowej z 2018 roku

\begin{tabular}{|c|c|c|}
\hline $\begin{array}{l}\text { NPP } \\
2018 \text { r. }\end{array}$ & $\begin{array}{c}\text { ZAKRES PODSTAWOWY } \\
\text { Cele kształcenia - wymagania ogólne }\end{array}$ & $\begin{array}{c}\text { ZAKRES ROZSZERZONY } \\
\text { Cele kształcenia - wymagania ogólne }\end{array}$ \\
\hline Geografia & II. Umiejętności i stosowanie & I. Wiedza geograficzna \\
\hline \multirow{3}{*}{$\begin{array}{l}\pi \\
3 \\
0 \\
3 \\
\pi \\
0 \\
0 \\
0 \\
0 \\
2 \\
0 \\
\pi \\
\pi \\
0 \\
0 \\
0\end{array}$} & $\begin{array}{l}\text { Korzystanie z planów, map fizyczno- } \\
\text { geograficznych i społeczno-gospodar- } \\
\text { czych, fotografii, zdjęć lotniczych i sate- } \\
\text { litarnych, rysunków, wykresów, danych } \\
\text { statystycznych, tekstów źródłowych, } \\
\text { technologii informacyjno-komunika- } \\
\text { cyjnych oraz geoinformacyjnych w celu } \\
\text { zdobywania, przetwarzania i prezen- } \\
\text { towania informacji geograficznych. }\end{array}$ & $\begin{array}{l}\text { 4. Zaznajomienie z geoinformacyjnymi } \\
\text { narzędziami analizy danych geogra- } \\
\text { ficznych. } \\
\text { 5. Rozumienie możliwości wykorzystania } \\
\text { technologii geoinformacyjnych } \\
\text { w poznawaniu świata i identyfiko- } \\
\text { waniu złożonych problemów środo- } \\
\text { wiska geograficznego. } \\
\text { II. Umiejętności i stosowanie wiedzy } \\
\text { w praktyce } \\
\text { 3. Wykonywanie podstawowych map } \\
\text { z wykorzystaniem narzędzi GIS. } \\
\text { 10. Wykorzystanie narzędzi GIS } \\
\text { w analizie i prezentacji danych } \\
\text { przestrzennych. }\end{array}$ \\
\hline & $\frac{\text { Treści nauczania - wymagania }}{\text { szczegółowe }}$ & $\frac{\text { Treści nauczania - wymagania }}{\text { szczegółowe }}$ \\
\hline & $\begin{array}{l}\text { Źródla informacji geograficznej, } \\
\text { technologie geoinformacyjne oraz } \\
\text { metody prezentacji danych prze- } \\
\text { strzennych... Uczeń: } \\
\text { 6) wykazuje przydatność fotografii } \\
\text { i zdjęć satelitarnych do pozyskiwa- } \\
\text { nia informacji o środowisku geogra- } \\
\text { ficznym oraz interpretuje ich treść; } \\
\text { 7) określa współrzędne geograficzne za }\end{array}$ & $\begin{array}{l}\text { I. Metody badań geograficznych i tech- } \\
\text { nologie geoinformacyjne: wywiady, } \\
\text { badania ankietowe, analiza źródeł } \\
\text { kartograficznych, wykorzystanie } \\
\text { technologii informacyjno-komuni- } \\
\text { kacyjnych i geoinformacyjnych do } \\
\text { pozyskania, tworzenia zbiorów, } \\
\text { analizy i prezentacji danych prze- } \\
\text { strzennych. Uczeń: }\end{array}$ \\
\hline$\sim$ & $\begin{array}{l}\text { pomocą odbiornika GPS; } \\
\text { 8) podaje przykłady wykorzystania } \\
\text { narzędzi GIS do analiz zróżnico- } \\
\text { wania przestrzennego środowiska } \\
\text { geograficznego. } \\
\text { VIII. ... Uczeń: } \\
\text { 15) korzysta z map cyfrowych dostęp- } \\
\text { nych w internecie w analizie sieci } \\
\text { osadniczej wybranych regionów } \\
\text { świata. } \\
\text { XIV. Regionalne zróżnicowanie środo- } \\
\text { wiska przyrodniczego Polski } \\
\text {...Uczeń: }\end{array}$ & $\begin{array}{l}\text { 3) stosuje wybrane metody kartogra- } \\
\text { ficzne do prezentacji cech ilościo- } \\
\text { wych i jakościowych środowiska } \\
\text { geograficznego i ich analizy } \\
\text { z użyciem narzędzi GIS; } \\
\text { 4) wykorzystuje odbiornik GPS do } \\
\text { dokumentacji prowadzonych obser- } \\
\text { wacji; } \\
\text { 5) wykorzystuje technologie informa- } \\
\text { cyjno-komunikacyjne i geoinfor- } \\
\text { macyjne do pozyskiwania, przecho- } \\
\text { wywania, przetwarzania i prezentacji } \\
\text { informacji geograficznych; }\end{array}$ \\
\hline
\end{tabular}




\begin{tabular}{|c|c|c|}
\hline 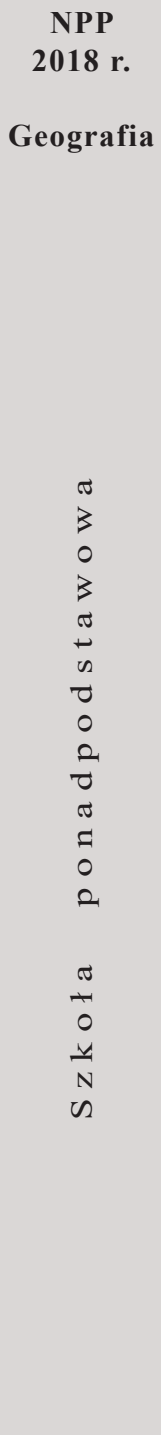 & $\begin{array}{l}\text { 10) korzystając z danych statystycz- } \\
\text { nych i aplikacji GIS, dokonuje } \\
\text { analizy stanu środowiska w Polsce } \\
\text { i własnym regionie oraz przedsta- } \\
\text { wia wnioski z niej wynikające; } \\
\text { XIV. ... Uczeń: } \\
\text { 14) projektuje wraz z innymi uczniami } \\
\text { trasę wycieczki uwzględniającą } \\
\text { wybrane grupy atrakcji turystycz- } \\
\text { nych w miejscowości lub regionie } \\
\text { oraz realizuje ją w terenie, wyko- } \\
\text { rzystując mapę i odbiornik GPS. }\end{array}$ & $\begin{array}{l}\text { V. Dynamika procesów geologicznych } \\
\text { i geomorfologicznych... Uczeń: } \\
\text { 8) dostrzega prawidłowości w rozmiesz- } \\
\text { czeniu zjawisk i procesów geologicz- } \\
\text { nych na Ziemi, wykorzystując } \\
\text { technologie geoinformacyjne. } \\
\text { XV. Zróżnicowanie społeczno-kulturowe } \\
\text { Polski... Uczeń: } \\
\text { 8) analizuje przestrzenne zróżnicowanie } \\
\text { preferencji wyborczych Polaków, } \\
\text { wykorzystując technologie geoinfor- } \\
\text { macyjne i dyskutuje nad przyczy- } \\
\text { nami tego zróżnicowania; } \\
\text { XVI. Elementy przestrzeni geograficz- } \\
\text { nej i relacje między nimi we włas- } \\
\text { nym regionie - badania i obserwa- } \\
\text { cje terenowe. Uczeń: } \\
\text { 4) na podstawie obserwacji oraz dostęp- } \\
\text { nych materiałów źródłowych } \\
\text { (np. miejscowego planu zagospoda- } \\
\text { rowania przestrzennego, geoportalu, } \\
\text { zdjęć satelitarnych) wyróżnia główne } \\
\text { funkcje i dokonuje oceny zagospoda- } \\
\text { rowania terenu wokół szkoły; } \\
\text { 5) wykorzystując dane GUS oraz narzę- } \\
\text { dzia GIS, analizuje strukturę użytko- } \\
\text { wania gruntów rolnych na terenach } \\
\text { wiejskich lub gruntów zabudowa- } \\
\text { nych i urbanizowanych na terenach } \\
\text { miejskich własnego regionu; } \\
\text { XVIII. Problemy środowiskowe współ- } \\
\text { czesnego świata...Uczeń: } \\
\text { 6) wykorzystuje zdjęcia satelitarne } \\
\text { i lotnicze oraz technologie geoinfor- } \\
\text { macyjne do lokalizowania i określa- } \\
\text { nia zasięgu katastrof przyrodniczych. }\end{array}$ \\
\hline
\end{tabular}

Źródło: opracowanie I. Piotrowska na podstawie MEN (2018a).

- wykorzystywanie aplikacji z zasobów Internetu,

- określanie powiązań i współwystępowania w przestrzeni,

- uzyskiwanie informacji oraz danych do opracowania prezentacji multimedialnej. Wśród rozwijanych umiejętności związanych z wykorzystywaniem baz danych należy zwrócić uwagę na klasyfikowanie, sortowanie oraz formułowanie zapytań, czyli przeszukiwanie danych za pomocą kryteriów według wartości lub atrybutów danych. Do najczęściej stosowanych można zaliczyć np. korzystanie 
z aplikacji, geoportali, z aplikacji mapowych, które pozwalają na zapoznawanie się np. z planami miast czy przeglądanie zdjęć satelitarnych. Bardzo kształcące jest korzystanie z programów, jak również oprogramowań do przeglądania danych przestrzennych, analizy np. uwarunkowań rozwoju przestrzennego wybranego obszaru, wykonywanie pomiarów odległości i powierzchni przy wykorzystaniu aplikacji czy też tworzenie profilu hipsometrycznego (Piotrowska 2018). Odpowiednio wykształcone umiejętności będą stanowiły podstawę do wyszukiwania jakichkolwiek informacji przestrzennych, przyrodniczych, społecznych, ekonomicznych, gospodarczych, kulturalnych itp. Obecność informacji geoprzestrzennej jest faktem i tylko trzeba umieć ją wykorzystać. A do tego zadania powinny właśnie przygotować nowe podstawy programowe geografii.

\section{Trudności i ograniczenia w realizacji założeń podstawy programowej dotyczących GIS}

Bardziej całościowe spojrzenie na możliwości edukacji w zakresie GIS, w kontekście nowych podstaw programowych, może budzić nadzieję na ich dostrzeżenie i stosowanie w geograficznym kształceniu. Zawarte w podstawie programowej dla szkoły ponadpodstawowej zapisy powinny wpłynąć pozytywnie na jakość geoinformacyjnego kształcenia. Jednak o tym, na ile te zapisy przełożą się na praktykę szkolną i oczekiwane efekty w zakresie wiedzy i umiejętności, trudno aktualnie jednoznacznie ocenić. Na możliwości poprawienia zakresu i jakości kształcenia posługiwania się technologiami geoinformacyjnymi i GIS składają się wielorakie uwarunkowania, które należy postrzegać również w kategoriach trudności i ograniczeń (ryc. 4). W kształceniu wiele zależy od różnorakich czynników, a szczególnie przygotowania nauczycieli, pokonania oporu mentalnego starszej kadry nauczycielskiej, wsparcia nauczycieli poprzez różne formy doskonalenia merytorycznego i dydaktycznego, istnienia odpowiednich materiałów szkoleniowych i podręczników, dostępności odpowiedniego oprogramowania, a przede wszystkim sprzętu komputerowego.

Włączenie w tak znacznym zakresie GIS do nowej podstawy programowej wymusza zatem nową jakość kształcenia. W początkowym okresie będzie to stanowiło bardzo duże wyzwanie dla nauczycieli geografii i konieczność dokształcania się, ponieważ te zagadnienia są nowe i nie istniały w programach studiów, kiedy zdecydowana większość nauczycieli kształciła się na studiach. Zgodnie z definicją terminu nauczyciel, to stałe doskonalenie się i aktualizowanie zarówno wiedzy, jak i ujęć metodycznych oraz umiejętności technologicznych, jest wpisane w ten zawód.

Jednak ze względu na nieliczne grono osób przygotowanych i chętnych do prowadzenia zajęć dokształcających dla nauczycieli, istnieje potrzeba instytucjonalnego wsparcia ze strony uczelni wyższych w zakresie organizacji studiów 


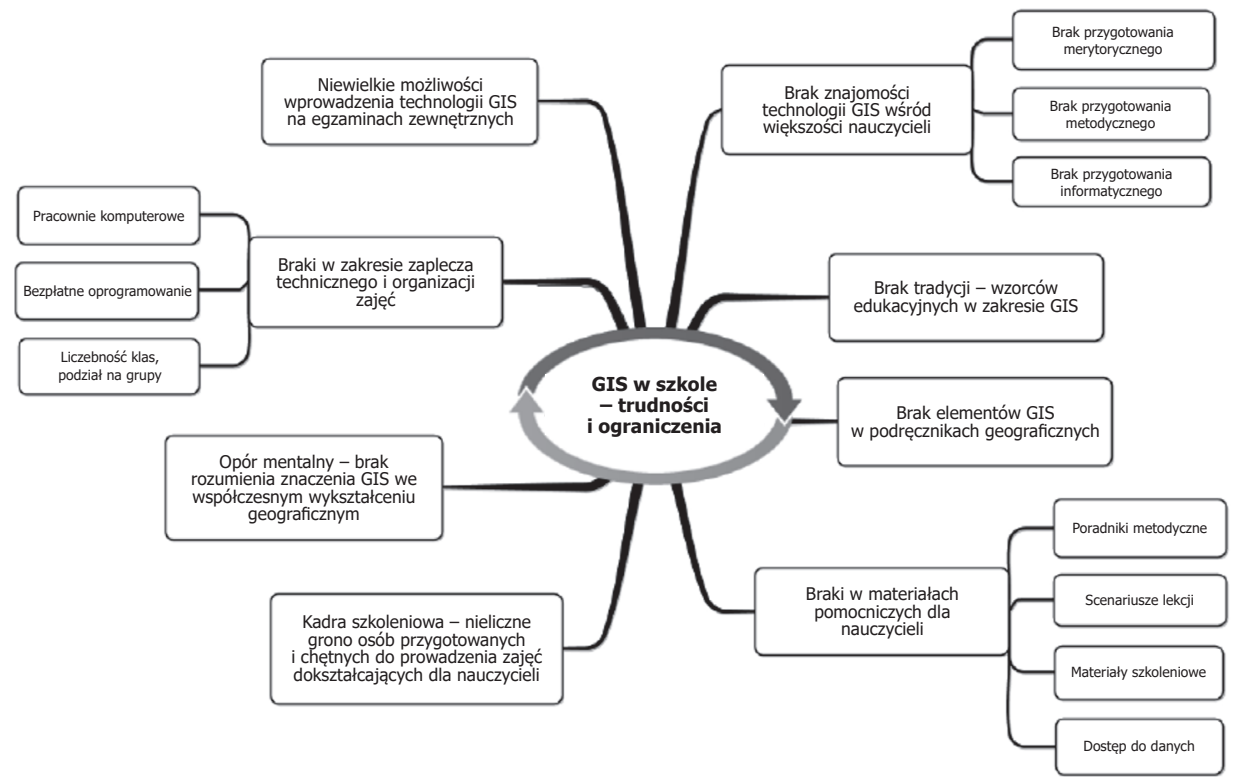

Ryc. 4. Trudności i ograniczenia w wykorzystaniu technologii geoinformacyjnych w praktyce szkolnej

Źródło: opracowanie E. Szkurłat.

podyplomowych i kursów podwyższających poziom wiedzy i umiejętności geoinformacyjnych aktualnych nauczycieli oraz rzetelnego przygotowania $\mathrm{w}$ tej dziedzinie przyszłych nauczycieli geografii (Jażdżewska 2016). Z uwagi na fakt, że od blisko dekady prowadzone są studia $\mathrm{z}$ zakresu geoinformacji na polskich uczelniach, na wydziałach geograficznych jest więc możliwość wykorzystania wiedzy oraz doświadczenia profesorów i nauczycieli akademickich (Kozak 2008; Kozak, Szablowska-Midor 2009; Jażdżewska, Werner, Zwoliński 2015). Zatem włączenie ich w proces kształcenia nauczycieli stanowić może nieocenioną pomoc w przygotowaniu do właściwej realizacji zapisów podstawy programowej geografii.

\section{Podsumowanie}

Wprowadzenie zagadnień GIS do podstawy programowej geografii jako zapisu obowiązkowego, stwarza warunki do kształcenia dostosowanego do rozwoju technologicznego, do kształtowania i doskonalenia kompetencji informatycznych oraz włączania ich w zakres edukacji geograficznej. Możliwość kształcenia geograficznego, np. w wirtualnym środowisku może ułatwić poznawanie odległych regionów na świecie. Uwzględniając założenia filozoficzne podstawy programowej, integrowanie wiedzy, włączanie ujęć humanistycznych oraz GIS, nowe podstawy programowe będą wpływały na skuteczność i efektywność nauczania 
geografii w powiązaniu z jej atrakcyjnością. Pojawienie się $\mathrm{w}$ podstawie programowej treści oraz efektów kształcenia dotyczących GIS i technologii geoinformacyjnych jest jak najbardziej współcześnie konieczne. Połączenie geografii $\mathrm{z}$ technologią cyfrową tylko może wzmocnić jej potencjał jako przedmiotu szkolnego oraz zwiększyć przekonanie o przydatności geografii w życiu społeczeństwa.

\section{Literatura}

Gaździcki J., 2006, Zakres tematyczny dziedziny geoinformacji jako nauki i technologii (Themes of GIScience and technology), ,Roczniki Geomatyki - Annals of Geomatics", Polskie Towarzystwo Informacji Przestrzennej, Warszawa, 4(2): 15-27.

Gaździcki J., 2009, Studia wyższe $w$ dziedzinie geoinformacji: aspekty modernizacji $w$ Polsce (Tertiary studies in geoinformation: aspects of modernization in Poland), „Roczniki Geomatyki - Annals of Geomatics”, Polskie Towarzystwo Informacji Przestrzennej, Warszawa, 7(3): 7-18.

Gaździcki J., Gotlib D., Jażdżewski I., Zwoliński Z., 2018, Aktualne aspekty edukacji geoprzestrzennej w Polsce, „Roczniki Geomatyki - Annals of Geomatics”, 16(3/82): 235-240.

GIS w szkole. Poradnik dla nauczycieli przedmiotów przyrodniczych, 2011, Centrum UNEP/GRID, Warszawa.

Głowacz A., 2015, Teoretyczne i praktyczne aspekty wykorzystania GIS w szkolnej edukacji, [w:] Hibszer A., Szkurłat E. (red.), Technologie informacyjno-komunikacyjne w geograficznej praktyce edukacyjnej, „Prace Komisji Edukacji Geograficznej Polskiego Towarzystwa Geograficznego", 5: 73-89.

Hibszer A., Piotrowska I., Rachwał T., Szkurłat E., 2017, Warunki realizacji nowej podstawy programowej ksztatcenia ogólnego. Geografia klasy V-VIII, „Geografia w Szkole”, 1: $35-37$.

Jażdżewska I. (red.), 2015, GIS in Higher Education in Poland. Curriculums, Issues, Discussion (GIS w szkolnictwie wyższym w Polsce. Programy, problemy, dyskusja), Wydawnictwo Uniwersytetu Łódzkiego, Łódź.

Jażdżewska I., 2016, Oferta edukacyjna geoinformacji na Wydziale Nauk Geograficznych Uniwersytetu Łódzkiego 2015/2016 r., ,Roczniki Geomatyki”, XIV, 3(73): 351-362.

Jażdżewska I., Werner P., Zwoliński Z., 2015, Current state and future perspectives of university education of GIS and geoinformation in Poland, [w:] Jażdżewska I. (red.), GIS in Higher Education in Poland. Curriculums, Issues, Discussion, Wydawnictwo Uniwersytetu Łódzkiego, Łódź: 5-23.

Kozak J., 2008, Nauczanie teorii i technologii informacji geograficznej na studiach geograficznych na Uniwersytecie Jagiellońskim: uwarunkowania i perspektywy, „Roczniki Geomatyki”, VI, 5: 39-48.

Kozak J., Szablowska-Midor A., 2009, Pożadane kompetencje absolwentów studiów geoinformatycznych: doświadczenia Instytutu Geografii i Gospodarki Przestrzennej Uniwersytetu Jagiellońskiego, „Roczniki Geomatyki”, VII, 6(36): 73-80.

Kroczak R., 2012, Systemy Informacji Geograficznej w szkole, „Geografia w Szkole”, 5: 6-10. 
MEN, 2017, Rozporzadzenie Ministra Edukacji Narodowej z dnia 14 lutego 2017 roku w sprawie podstawy programowej wychowania przedszkolnego oraz podstawy programowej kształcenia ogólnego dla szkoły podstawowej, w tym dla uczniów z niepetnosprawnościa intelektualna w stopniu umiarkowanym lub znacznym, kształcenia ogólnego dla branżowej szkoły I stopnia, kształcenia ogólnego dla szkoły specjalnej przysposabiającej do pracy oraz kształcenia ogólnego dla szkoły policealnej (Dz.U., 2017, poz. 356).

MEN, 2018a, Rozporzadzenie Ministra Edukacji Narodowej z dnia 30 stycznia 2018 roku w sprawie podstawy programowej kształcenia ogólnego dla liceum ogólnokształcacego, technikum oraz branżowej szkoły II stopnia (Dz.U., 2018, poz. 467).

MEN, 2018b, Rozporzadzenie Ministra Edukacji Narodowej z dnia 26 lipca 2018 roku zmieniajace rozporzadzenie $w$ sprawie podstawy programowej wychowania przedszkolnego oraz podstawy programowej kształcenia ogólnego dla szkoły podstawowej, $w$ tym dla uczniów z niepetnosprawnościa intelektualna $w$ stopniu umiarkowanym lub znacznym, kształcenia ogólnego dla branżowej szkoły I stopnia, kształcenia ogólnego dla szkoty specjalnej przysposabiajacej do pracy oraz kształcenia ogólnego dla szkoły policealnej (Dz.U., 2018, poz. 1679).

Nita J., Waga J.M., 2004, GIS w nauczaniu geografii: projekt TERRA-INFO-0597: możliwość wykorzystania baz danych, „Geografia w Szkole”, 3: 15-22.

Piotrowska I., 1996, Wykorzystanie Geograficznych Systemów Informacyjnych w nauczaniu geografi, [w:] Jarowiecki J., Piskorz S. (red.), Różne drogi kształcenia i doksztatcania nauczycieli geografii, Akademia Pedagogiczna w Krakowie, Kraków: 136-143.

Piotrowska I., 2018, Technologie geoinformacyjne w podstawie programowej-wyzwanie dla nauczyciela geografii, [w:] Hibszer A., Szkurłat E. (red.), Nauczyciel geografii wobec wyzwań reformowanej szkoty, „Prace Komisji Edukacji Geograficznej Polskiego Towarzystwa Geograficznego", 8, Sosnowiec: 33-50.

Piotrowska I., Hibszer A., Szkurłat E., Rachwał T., 2017, Nowa podstawa programowa z geografii w szkole podstawowej - komentarze $i$ odpowiedzi do opinii, „Geografia w Szkole", 2: 18-21.

Samulowska M., Wyka E., 2015, Nauczanie z wykorzystaniem narzędzi GIS - przykłady rozwijania umiejętności analizowania informacji przestrzennych, [w:] Hibszer A., Szkurłat E. (red.), Technologie informacyjno-komunikacyjne w geograficznej praktyce edukacyjnej, „Prace Komisji Edukacji Geograficznej Polskiego Towarzystwa Geograficznego", 5, Łódź: 89-104.

Szkurłat E., 2011, Idee Wacława Nałkowskiego a współczesna dydaktyka, [w:] Kurek S. (red.), Koncepcje Wacława Natkowskiego w świetle osiagnięć współczesnej nauki i filozofii, „Studia Geographica II. Annals Universitatis Pedagogicae Cracoviensis”, 105, Wydawnictwo Naukowe Uniwersytetu Pedagogicznego, Kraków: 110-117

Szkurłat E., Hibszer A., Angiel J., 2016, Zarys koncepcji szkolnej edukacji geograficznej, „Geografia w Szkole”, 5: 18-22.

Szkurłat E., Hibszer A., Piotrowska I., Rachwał T., 2017a, Komentarz do podstawy programowej geografia na II etapie edukacyjnym, [w:] Podstawa programowa kształcenia ogólnego z komentarzem; szkoła podstawowa, geografia, Ośrodek Rozwoju Edukacji, Warszawa: 24-36. 
Szkurłat E., Piotrowska I., Hibszer A., Rachwał T., Wieczorek T., 2017b, Nowa podstawa programowa z geografii dla liceum ogólnokształcacego oraz technikum - ogólne założenia $i$ warunki realizacji, „Geografia w Szkole”, 3: 26-31.

Zwoliński Z., 2009a, Rozwój myśli geoinformacyjnej, [w:] Zwoliński Z. (red.), GIS - platforma integracyjna geografii, Bogucki Wydawnictwo Naukowe, Poznań: 9-21.

Zwoliński Z. (red.), 2009b, GIS - platforma integracyjna geografii (GIS - geography integration platform), Bogucki Wydawnictwo Naukowe, Poznań.

Zwoliński Z., 2010, O homologiczności polskiej terminologii geoinformacyjnej (On homology of the Polish geoinformation terminology), [w:] Zwoliński Z. (red.), GIS - woda w środowisku, Bogucki Wydawnictwo Naukowe, Poznań: 21-30.

\title{
Akty prawne
}

Europejskie Ramy Kwalifikacji dla uczenia się przez całe życie (Dz.Urz.UE C $111 \mathrm{z}$ dnia 6 maja 2008 r.).

\section{GIS IN THE NEW CORE CURRICULUM OF GEOGRAPHY}

\begin{abstract}
In recent years, educational activities have been undertaken, the effect of which is a change in philosophy and ways of geographic education, related to the development of a knowledge-based economy and digital technologies. The article discusses the general assumptions and directions of changes in the new geography program basis, with particular emphasis on the role of geoinformation technologies and GIS. Also, the relevant provisions have been presented, emphasizing the need to introduce them in the implementation of specific substantive issues from both physical and socio-economic geography. Since the introduction of GIS to such a large extent is a new situation and a big challenge for teachers, attention was also paid to the possible difficulties and limitations in the implementation of the core curriculum. Being aware of this, it is also important to take specific solutions and proposals in the field of teacher education in relation to program changes.
\end{abstract}

Keywords: Geographic Information Systems, the geoinformation technology, the core curriculum, geography.

Dr hab. Elżbieta Szkurłat, prof. UŁ Instytut Geografii

Wydział Kultury Fizycznej, Zdrowia i Turystyki Uniwersytet Kazimierza Wielkiego w Bydgoszczy e-mail: ela.szkurlat@gmail.com

Dr hab. Iwona Piotrowska, prof. UAM Pracownia Dydaktyki Geografii i Edukacji Ekologicznej Instytut Geoekologii i Geoinformacji Wydział Nauk Geograficznych i Geologicznych Uniwersytet im. Adama Mickiewicza w Poznaniu e-mail: ipiotrow@amu.edu.pl 